\title{
The Influence of Process Energy on the Yield of Asymmetric Curcumin Analog from Cullilawan Oil
}

\author{
Imanuel Berly Delvis Kapelle ${ }^{1}$, Tun Tedja Irawadi ${ }^{2}$, Meika Syahbana Rusli ${ }^{3}$, \\ Nini Munirah Renur ${ }^{4}$ \\ 1(Chemistry Department, Mathematic and Natural Science Faculty, Pattimura University, Indonesia) \\ 2(Chemistry Department, Mathematic and Natural Science Faculty, IPB, Indonesia) \\ 3(Agricultural Industry Technology Department, Agriculture Technology Faculty, IPB, Indonesia) \\ 4(Fishery Product Technology, Polytechnic State Fisheries Tual, Maluku Southeast, Indonesia)
}

\begin{abstract}
Asymmetric curcumin analogue compound is an anticancer compound synthesized from cullilawan oil with several stages of the process such as; Isolation of safrol from cullilawan oil, safol isomerisation, oxidation, intermediate product synthesis and asymmetric curcumin analog synthesis. The amount of energy used for asymmetric curcumin analog synthesis process gives effect to yield. The purpose of this research is to know the effect of process energy on asymmetric curcumin analogue yield from lawang oil. The results of the study showed that the synthesis of curcumin analogue compounds using microwave method on different energy quantities $(8.4 \mathrm{~kJ}, 25.2 \mathrm{~kJ}, 33.6 \mathrm{~kJ}$, $75 \mathrm{~kJ})$ gives effect to yield. The greater the energy used in the process will lower the yield and the energy that gives the highest yield is $8.4 \mathrm{~kJ}$.
\end{abstract}

Keywords: asymmetric curcumin analogues, microwaves method, Energy, cullilawan oil

\section{Introduction}

Cancer is the second most common cause of death in the world [1] and breast cancer is the leading cause of death in women due to metastasis of the cancer [2]. Proven natural ingredients as anticancer are curcumin [3,4], curcumin analogues [5,6]. The activity of each compound is influenced by functional groups and structures as well as affecting the physical-chemical properties and pleiotropic effects [7]. The active side of the curcumin analogue that gives effect is the phenolic group and the conjugated double bond [8]. Breast cancer anticancer activity for curcumin analogue compound which gives the active side is the carbon atom in the phenol group [9]. Piperine is an alkaloid compound that has been tested for its activity as an antitumor by in vivo method can inhibit 56.8\% [10], antioxidant, hepatoprotective effects [11] and anticancer because it has an active dioxolane ring. The curcumin analogue compound which has a dioxolane ring tested for cytotoxic activity on breast cancer cell cultures gives a positive result [12]. The compound that has a dioxolane ring that can be used as a precursor is safrol. Safrol is present in cullilawan oil and can be isolated using chemical and physical methods $[13,14]$.

Asymmetric curcumin analogue (5-benzo [1,3] dioxol-5-yl-1-phenyl-penta-2,4-dien-1-one) is a curcumin analog compound synthesized from culilawan oil using several stages of the reaction. The curcumin analog compound is obtained from the condensation reaction between the intermediate product $(3$-Benzo $[1,3]$ dioxol-5-yl-propenal) and acetophenone under alkaline conditions [14]. The cytotoxic activity of the compound is also affected by the process method, in which thermodynamic control affects the product. Stable products due to thermodynamic control provide better inhibitory activity if the process conditions without heat effect [12]. The results of anti-cancer activity test for asymteris curcumin analogue showed the most active asymteris curcumin analogue with microwave method. Percent yield of the synthesis of asymmetric curcumin analogue using microwave method at 140 watt power with 2 minute heating time (energy $16.8 \mathrm{~kJ}$ ) was $82.82 \%$. The amount of energy used for asymmetric curcumin analog synthesis process gives effect to yield. The purpose of this research is to know the effect of process energy on asymmetric curcumin analogue yield from culilawan oil.

\subsection{Material}

\section{Material And Method}

Cullilawan oils from Maluku-Indonesia, $\mathrm{NaOH}, \mathrm{KOH}, \mathrm{KMnO}_{4}, \mathrm{CH}_{3} \mathrm{COOH}, \mathrm{Na}_{2} \mathrm{SO}_{4}, \mathrm{H}_{2} \mathrm{SO}_{4}$, Diethyl ether, and acetofenone petroleum ether, Dichloromethane, Methanol, Acetaldehyde and Polisorbat (Tween 80). The influence of process energy on the yield of asymmetric curcumin analog from cullilawan oil www.iosrjournals.org 2 |Page 


\subsection{Isolation safrole}

$137.42 \mathrm{~g}$ Cullilawan oils was added $40 \mathrm{~g}$ of $\mathrm{NaOH}$ in $300 \mathrm{~mL}$ of Aquades. The mixture was stirred to form two layers, and then the upper layer was separated. The bottom layer was extracted twice with $100 \mathrm{~mL}$ of petroleum ether and added to the top layer, then washed with distilled water until neutral and dried with $\mathrm{Na}_{2} \mathrm{SO}_{4}$ anhydrous. Petroleum ether was separated using evaporator and conducted distillation at reduced pressure.

\subsection{Isomerization of safrole}

Into a three-neck flask $500 \mathrm{~mL}$ size that has been equipped with a magnetic stirrer, thermometer, cooling tube, and blue silica gel. Added $71.56 \mathrm{~g}(0.44 \mathrm{~mol})$ safrole and $50 \mathrm{~g}(0.89 \mathrm{~mol}) \mathrm{KOH}$. The mixture was refluxed at a temperature of $120^{\circ}$ for 6 hours, and cooled then added $250 \mathrm{~mL}$ of aquades and then extracted with diethyl ether. Results dried with $\mathrm{Na}_{2} \mathrm{SO}_{4}$ and diethyl ether separated using evaporator. Purification was performed using distilled under reduced pressure.

\subsection{Synthesis of piperonal}

Into a $250 \mathrm{~mL}$ three-neck flask included $2.97 \mathrm{~g}(0.02 \mathrm{~mol})$ isosafrole, $100 \mathrm{~mL}$ aquades, $2 \mathrm{~mL}$ $\mathrm{CH}_{3} \mathrm{COOH}, 15 \mathrm{ml} \mathrm{H}_{2} \mathrm{SO}_{4} 50 \%, 100 \mathrm{mg}$ twin 80 and $100 \mathrm{~mL}$ dichloromethane. Further $9.79 \mathrm{~g}(0.062 \mathrm{~mol})$ $\mathrm{KMnO}_{4}$ was added about $500 \mathrm{mg}$ every minute, the temperature is $<30{ }^{\circ} \mathrm{C}$ by placing in an ice bath. After $\mathrm{KMnO}_{4}$ added, the flask is heated slowly at $40{ }^{\circ} \mathrm{C}$ until the purple color disappeared ( 15 minutes). The solution is cooled for a few minutes and precipitate $\mathrm{MnO}_{2}$ filtered using silica gel. Separation of the resulting solution is then poured into a separating funnel and the layers separated. Water layer (upper layer) was extracted with dichloromethane $(2 \times 30 \mathrm{~mL})$. All organic layers are combined, and then washed with $2 \times 30 \mathrm{~mL}$ aquades. The organic layer was dried with $\mathrm{Na}_{2} \mathrm{SO}_{4}$, filtered and evaporated at the evaporator. The residue was added $20 \%$ $\mathrm{NaOH}$ solution and the mixture was stirred for 30 minutes. Furthermore, the mixture was extracted with dichloromethane, washed with aquades, dried with $\mathrm{Na}_{2} \mathrm{SO}_{4}$ anhydrous and evaporated back.

\subsection{Synthesis of 3-Benzo[1,3]dioxol-5-yl-propenal}

An intermediate product done by mixing $16 \mathrm{~g}(0.4 \mathrm{~mol}) \mathrm{NaOH}, 100 \mathrm{ml}$ aquades and $150 \mathrm{ml}$ methanol. Stirred the mixture, next $8.8 \mathrm{~g}(0.2 \mathrm{~mol})$ acetaldehyde a mixture is poured into. As many as $30 \mathrm{~g}(0.2 \mathrm{~mol})$ piperonal poured into mix and stirred for 3 hours. The result then cooled and included in refrigerator for 12 hours. Solids results filtered with filters Buchner and washed with aquades until neutral. Crystals that formed in a recrystallization and analyzed.

\subsection{Synthesis process conditions asymmetric curcumin analogues}

A method of microwave by way of mixing $3.2 \mathrm{~g}(0.08 \mathrm{~mol}) \mathrm{NaOH}, 20 \mathrm{ml}$ aquades and $30 \mathrm{ml}$ methanol. A mixture of stirred, next $(0.04 \mathrm{~mol})$ acetofenone poured into the mix and stirred immediately. As many as 7.04 $\mathrm{g}(0.04 \mathrm{~mol})$ an intermediate product is poured into a mixture of. Included a mixture of resources into the microwave on the energi $(8,4 \mathrm{~kJ} ; 25,2 \mathrm{~kJ} ; 33,6 \mathrm{~kJ} ; 75 \mathrm{~kJ})$. Then cooled and included in the refrigerator for 12 hours. Strained by the results of the solids Buchner and washed with aquades until the $\mathrm{pH}$ neutral. Crystals formed in a recrystallization and analyzed.

\subsection{Isolation safrole}

\section{Results And Discussion}

Safrole can be separated from cullilawan oils by using $\mathrm{NaOH}$. Eugenol and other phenolic components will react with $\mathrm{NaOH}$ to form water-soluble salts and formed two layers that can be separated, safrole layer which is not soluble in water are at the top of the mixture. Safrole were then purified using fractionation distillation at pressure reduction. In Fraction 2 at temperatures $90-123{ }^{\circ} \mathrm{C} / 1 \mathrm{mmHg}$ obtained safrole with yield $19.30 \%$. The properties of the resulting safrole is a clear liquid form, fragrant, insoluble in water but soluble in ethanol, chloroform and ether. Safrole analysis using gas chromatography obtained with a purity of $89.186 \%$ safrole. Infrared spectrum of safrole shows absorption bands in the region 3000-2800 cm-1 which is the absorption $\mathrm{Csp}_{3}-\mathrm{H}$, this was confirmed by the appearance of absorption at $1442.7 \mathrm{~cm}-1$ for $-\mathrm{CH}_{2}$ - (methylene). Uptake range of $\mathrm{C}=\mathrm{C}$ aromatic absorptions appeared at $1608.5 \mathrm{~cm}-1$ and is supported by absorption at $3150-3000$ $\mathrm{cm}-1$ which is the absorption band for $=\mathrm{Csp} 2-\mathrm{H}$ (aromatic). Absorption band at $1247 \mathrm{~cm}-1$ region and $1041 \mathrm{~cm}-1$ shows the range of C-O-C (ether) supported by each tape $916 \mathrm{~cm}-1$ and $808 \mathrm{~cm}-1$. Analysis and interpretation safrole ${ }_{1 \mathrm{H}}$-NMR spectrum (fig.1) are as follows; $\delta=3.2 \mathrm{ppm}\left(\mathrm{d},-\mathrm{CH}_{2}\right), \delta=5.0 \mathrm{ppm}\left(\mathrm{d}=\mathrm{CH}_{2}\right), \delta=5.5$ to 6.2 $\mathrm{ppm}(\mathrm{m},=\mathrm{CH}-), \delta=5.9 \mathrm{ppm}\left(\mathrm{s},-\mathrm{O}-\mathrm{CH}_{2}-\mathrm{O}-\right), \delta=6.8 \mathrm{ppm}(\mathrm{m}, 3 \mathrm{H} \mathrm{Ar})$. Safrole analysis using mass spectrum gives the following description, (m / z): 39, 51, 63, 77, 91, 104, 119, 131, and $162\left[\mathrm{C}_{10} \mathrm{H}_{10} \mathrm{O}_{2}\right]_{+}$(base peak). The influence of process energy on the yield of asymmetric curcumin analog from cullilawan oil www.iosrjournals.org 3 |Page 


\subsection{Isomerization of safrole}

Isosafrole can be carried on without solvent system using $\mathrm{KOH}$ at $120{ }^{\circ} \mathrm{C}$ for 8 hours and obtained yield $77.56 \%$. The properties of the resulting isosafrole is light yellow viscous liquid and fragrant. Analysis using gas chromatography obtained cis-isosafrole the 3 rd peak with a retention time of 3.375 minutes $(15.40 \%)$ and trans-isosafrole the peak-to-5 with a retention time of 3.700 minutes $(69.34 \%)$. Infrared spectrum of isosafrole showed absorption at area $3000-2800 \mathrm{~cm}-1$ which is Csp3-H absorption. Absorption range of $\mathrm{C}=\mathrm{C}$ aromatic appeared at $1608 \mathrm{~cm}-1$. Absorption band Csp2-H (aromatic) appears in the area 3150-3000 cm-1, this conclusion is supported by the presence of sharp band with moderate strength at $1490 \mathrm{~cm}-1$. Absorption at 1247 to $1091 \mathrm{~cm}-1$ shows the range of the C-O-C. Analysis and interpretation safrole ${ }_{1} \mathrm{H}-\mathrm{NMR}$ spectrum are as follows; $\delta=1.8 \mathrm{ppm}\left(\mathrm{d},-\mathrm{CH}_{3}\right), \delta=5.9 \mathrm{ppm}\left(\mathrm{s},-\mathrm{O}_{-} \mathrm{CH}_{2}-\mathrm{O}-\right), \delta=6.3 \mathrm{ppm}(\mathrm{d},-\mathrm{CH}=), \delta=6.7-6.9 \mathrm{ppm}(\mathrm{d}, \mathrm{H} \mathrm{Ar})$. Indications of changes in safrole be isosafrol visible from signal loss $\left(-\mathrm{CH}_{2}-\right)$ in area $3.2 \mathrm{ppm}$ safrole and formation methyl signal in area $1.8 \mathrm{ppm}$.

\subsection{Synthesis of piperonal}

Piperonal properties produced in the form of white crystals and fragrant, insoluble in water but soluble in methanol (mp $56-57{ }^{\circ} \mathrm{C}$ ). The results obtained by recrystallization using methanol piperonal to yield $65.63 \%$. Infrared spectrum of piperonal obtained their range $\mathrm{C}=\mathrm{C}$ aromatic appearing on uptake $1604 \mathrm{~cm}-1$ is supported by absorption above $3000 \mathrm{~cm}-1$ as absorption Csp2- $\mathrm{H}$ (aromatic). Absorption area between 3000-2800 cm-1 which indicates the absorption Сsp3-H are reinforced by the presence of absorption $1448 \mathrm{~cm}_{-1}$ and $1357 \mathrm{~cm}-1$ for methylene group (- $\left.\mathrm{CH}_{2}-\right)$. Aldehyde group is shown by the presence of a weak absorption in the area twins 2711 $\mathrm{cm}-1$ and $2781 \mathrm{~cm}-1$ which is very typical for aldehyde compound. This was confirmed by uptake $1689 \mathrm{~cm}-1$ which shows the carbonyl group. Absorption band $1249 \mathrm{~cm}_{-1}, 1099 \mathrm{~cm}-1$ and $1037 \mathrm{~cm}-1$ shows the compound ether. Besides the loss of the double bond in isosafrole characterized by loss of absorption area at $962.4 \mathrm{~cm}-1$. Analysis and interpretation safrole ${ }_{1} \mathrm{H}-\mathrm{NMR}$ spectrum are as follows; $\delta=5.9 \mathrm{ppm}\left(\mathrm{d},-\mathrm{O}-\mathrm{CH}_{2}-\mathrm{O}-\right), \delta=6.9 \mathrm{ppm}$ $(\mathrm{d}, 1 \mathrm{H} \mathrm{Ar}), \delta=7.2 \mathrm{ppm}(\mathrm{d}, 2 \mathrm{H} \mathrm{Ar}), \delta=9.9 \mathrm{ppm}(\mathrm{d}, \mathrm{CH}=\mathrm{O})$. Hints of the data ${ }_{1} \mathrm{H}-\mathrm{NMR}$ is a powerful clue oxidation of the double bond isosafrole is $\delta=9.9 \mathrm{ppm}$ peak which is the aldehyde proton unprotected because the induction effect of the carbonyl oxygen atom which is electronegative.

\subsection{Synthesis of 3-Benzo $[1,3]$ dioxol-5-yl-propenal}

An intermediate product 3-Benzo[1,3]dioxol-5-yl-propenal obtained from condensation piperonal reaction with acetaldehyde having yield $70.28 \%$.Time retention 12.43 minutes to an intermediate product with purity $23.59 \%$ showed compound with the molecular weight of $176 \mathrm{~g} / \mathrm{mol}$. The product that has the highest concentration in the retention 9,58 minute is piperonal who had not participated in react. Synthesis of compounds 3-benzo[1,3]dioxol-5-yl-propenal based on Claisen-Schmidt reaction involving two stages reaction. The first stage is an addition reaction nucleophile stage. At this stage carboanion of acetaldehyde will attack the carbonyl group on piperonal. The results of an addition reaction nucleophile above will experience the transfer of protons from the molecule of water produces $\beta$-hydroxyketone. Reaction the second stage is dehydration compound $\beta$-hydroxyketone because compound $\beta$-hydroxyketone have atoms $\mathrm{H} \alpha$ against the carbonyl group, so that in the course of an alkali atoms $\mathrm{H} \alpha$ easily off. It is speed up dehydration compound $\beta$ - hydroxyketone produce products with stable because they have the double bond that conjugated aromatic within the ring. A product produced purity all produce low caused due comparative concentration vested equally among acetaldehyde with piperonal so that in the final outcome there are piperonal that is not be fit react.

\subsection{Synthesis process conditions asymmetric curcumin analogues}

Asymmetric curcumin analogue synthesis results using some amount of process energy for reaction between acetophenone and intermediate product obtained by orange crystals and data can be seen in table 1 .

Table 1. Asymmetric curcumin analogue synthesis results

\begin{tabular}{cccccccc}
\hline No & $\begin{array}{c}\text { Power } \\
(\text { watt })\end{array}$ & $\begin{array}{c}\text { Time } \\
(\text { minute })\end{array}$ & $\begin{array}{c}\text { Energy } \\
(\mathrm{kJ})\end{array}$ & $\begin{array}{c}\text { Synthesis } \\
\text { results } \\
(\%)\end{array}$ & $\begin{array}{c}\text { Melting } \\
\text { point } \\
\left({ }^{\circ} \mathrm{C}\right)\end{array}$ & $\begin{array}{c}\text { Purity based } \\
\text { on HPLC } \\
(\%)\end{array}$ & Yield (\%) \\
\hline 1 & 140 & 1 & 8,4 & 95,95 & 121,5 & 99,643 & 95,60 \\
2 & 140 & 3 & 25,2 & 70,50 & 103,7 & 92,398 & 65,14 \\
3 & 280 & 2 & 33,6 & 55,89 & 122,6 & 98,619 & 55,11 \\
4 & 420 & 3 & 75,76 & 52,33 & 107,1 & 94,880 & 49,65 \\
\hline
\end{tabular}




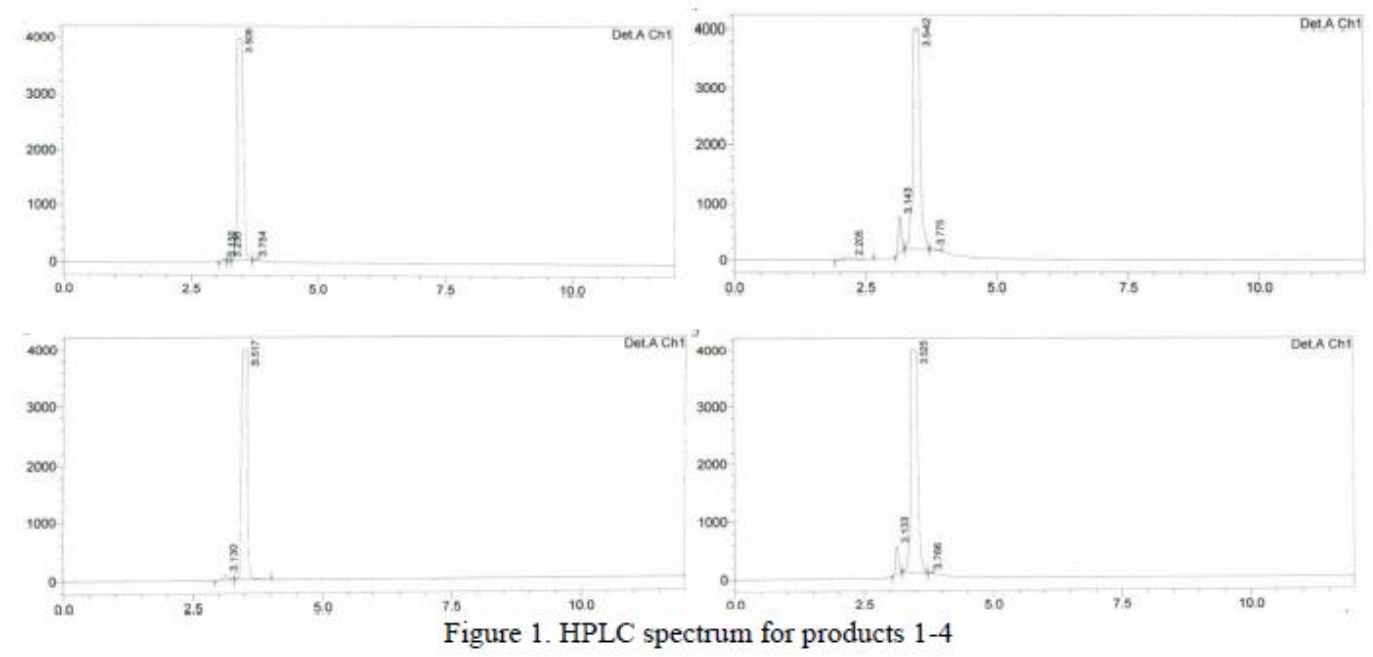

The synthesis of asymmetric curcumin analogue using microwave method on different energy quantities gives effect to yield. From Fig. 2 it is seen that the greater the energy used in the process will decrease the yield and percent of the synthesis results. The magnitude of the process energy that gives the highest yield is $8.4 \mathrm{~kJ}$. The use of microwave radiation was also performed by Azarifar [15] for condensation reaction yielding several products with 300 watt power for several minutes and $80-95 \%$ yield. However, the effect of energy does not have an impact on product purity based on HPLC data. Microwave radiation causes warming of all materials that improve the efficiency and reproducibility of chemical processes [16]. When the material is exposed to microwave radiation, the interaction of the ingredients in the mixture is different [17]. The heating mechanism of microwaves is polarization of dipolar, interfacial polarization, conduction mechanism [18].

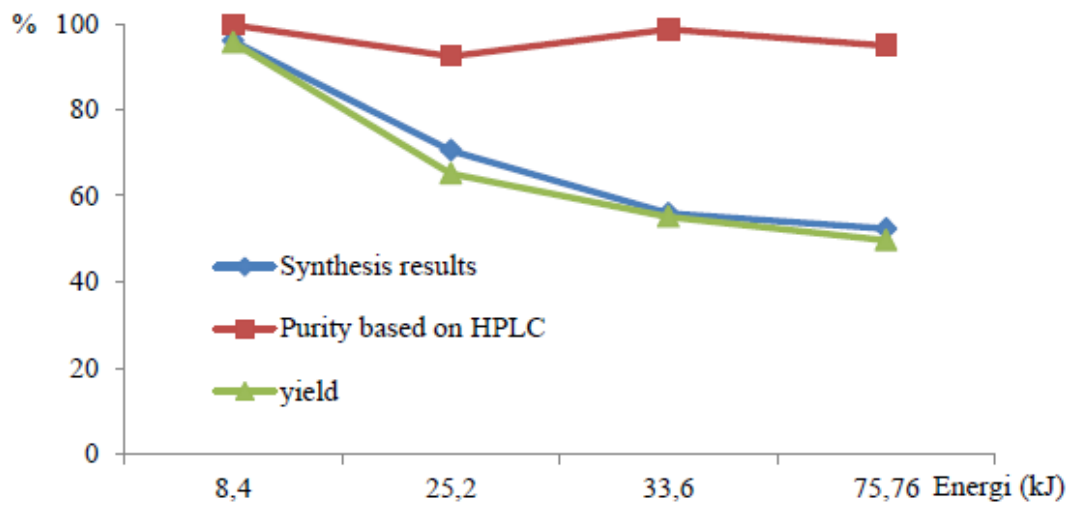

Figure 2. Graph of the relationship between process energy and synthesis results, purity based on HPLC, Yield

\section{Conclusion}

Asymmetric curcumin analogs from culilawan oils synthesized using different amounts of process energy have an effect on yield. The greater the energy used in the process will decrease the yield and the energy that gives the highest yield is $8.4 \mathrm{~kJ}$. The influence of process energy on the yield of asymmetric curcumin analog from cullilawan oil www.iosrjournals.org 5 | Page

\section{References}

[1] D.N. do Amaral, B.C Cavalcanti, D.P. Bezerra, P.M.P. Ferreira, R.D.P. Castro. Docking, synthesis and antiproliferative activity of n-acylhydrazone derivatives designed as combretastatin A4 analogues. Plos one, 9(3), 2014, e85380.

[2] DeMore KN, Zee KJV, Linkov I, Borgen PI, Gerald WL. 2001. Biological behavior of human breast cancer micrometastases. Clin Cancer Res. 7:2434-2439.

[3] C Moorthi, K. Kathiresan. Curcumin-piperine/curcumin-quercetin/ curcumin-silibinin dual drug-loaded nanoparticulate combination therapy: a novel approach to target and treat multidrug-resistant cancers. J Med Hypoth Ide, 7, $2013,15-20$.

[4] Y Qian, P. Zhong, D. Liang, Z. Xu, M. Skibba, C. Zeng, et al. A newly designed curcumin analog y20 mitigates cardiac injury via anti-inflammatory and anti-oxidant actions in obese rats. Plos one, 10(3), 2015, e0120215. 
[5] Y.J. Shang, X.L. Jin, X.L. Shang, J.J. Tang, G.Y.Liu, F. Dai, Y.P Qian, G.J Fan, G Liu, B Zhou. Antioxidant capacity of curcumindirected analogues: Structure-activity relationship and influence of microenvironment. J Food Chem, 119, $2010,1435-1442$.

[6] P Anand, S Bokyung, Ajaikumar, A.B Kunnumakkara, K.N Rajasekharan, Bharat, Aggarwal BB. Suppression of pro-inflammatory and proliferative pathways by diferuloylmethane (curcumin) and its analogues dibenzoylmethane, dibenzoylpropane, and dibenzylideneacetone: Role of Michael acceptors and Michael donors. J Biochem Pharm. 82, 2011, 1901-1909.

[7] P Anand, S Chitra, J Sonia, A.B Kunnumakkara, B.B Aggarwal. Curcumin and cancer: An "old-age" disease with an "age-old" solution. Cancer Let, 267, 2008, 133-164.

[8] T Devasena, K.N Rajasekaran, V.P Menon. Bis-1,7-(2-hydroxyphenyl)-hepta-1,6-diene-3,5-dione (a curcumin analog) ameliorates dmh-induced hepatic oxidative stress during colon carcinogenesis. Pharm Res, 46, 2002, 1.

[9] Q Zhang, Y Zhong, L.N Yan, X Sun, T Gong, Z.R Zhang. Synthesis and preliminary evaluation of curcumin analogues as cytotoxic agents. J Bioorg Med Chem Let, 21, $2011,1010-1014$.

[10] B.D Bezerra, F.O Castro, A.P.N.N Alves, C Pessoa, M.O Moraes, E.R Silveira, M.A.S Lima, F.J.M Elmiro, L.V Costa-Lotufo. In vivo growth-inhibition of Sarcoma 180 by piplartine and piperine, two alkaloid amides from piper. Brazilian J Medic Bio Res, 39 , 2006, 801-807.

[11] A Mehta, G Kaur, M Chintamaneni. Piperine and quercetin enhances antioxidant and hepatoprotective effect of curcumin in paracetamol induced oxidative stress. Int J Pharm, 8(2), 2012, 101-107.

[12] I.B.D Kapelle, T.T Irawadi, M.S Rusli, D Mangunwidjaja, Z.A Mas'ud. The Influence of Synthesis Methods Against Anti-Cancer Activity of Curcumin Analogous. Cancer Research Journal, 3(4), 2015, 68-75.

[13] I.B.D Kapelle, T.T Irawadi, M.S Rusli, D Mangunwidjaja, Z.A Mas'ud. Synthesis of New Curcumin Analogues from Kulit Lawang Oils Using the Conventional Method and Microwave. Science Journal of Chemistry, 3(3), 2015, 50-56.

[14] I.B.D Kapelle, T.T Irawadi, M.S Rusli, D Mangunwidjaja, Z.A Mas'ud. Synthesis of Asymmetric Curcumin analogues from Cullilawan Oil using Conventional and Microwave Method. Procedia Chemistry, 16, 2015, 480 - 488.

[15] D Azarifar, H Ghasemnejad. Microwave-assisted synthesis of some 3,5-arylated 2-pyrazolines. Molecules, 8, 2003:642-648.

[16] E Calce, V Bugatti, V Vittoria, S De Luca.Solvent-free synthesis of modified pectin compounds promoted by microwave irradiation. Molecules, 17, 2012, 12234-12242.

[17] S.M Al-Mousawi, M.A El-Apasery, M.H Elnagdi. Microwave assisted dyeing of polyester fabrics with disperse dyes. Molecules, $18,2013,11033-11043$.

[18] S.S Lam, H.A Chase. A review on waste to energy processes using microwave pyrolysis. Energies, 5, 2012, 4209-4232 